folk/ed. 2021; 27(2): 357-377

DOI: $10.22559 /$ folklor.1607

\title{
Türk Halk Kültürü Geçiş Dönemi Ritüellerinde Yumurta *
}

\author{
Egg in Rituals of the Transition Period of Turkish Folk \\ Culture
}

\section{Rezan Karakaş ${ }^{* *}$}

$\ddot{O} \mathbf{z}$

Yumurta, Türk ve dünya mitolojilerindeki birçok anlatıda dünyanın, tanrıların, yarı tanrıların ve insanın yaradılışı yahut kahramanların doğumuyla ilişkili hadiselerde karşımıza çıkar. Yumurtanın simgesel anlamı, tarih öncesi devirlerden bu yana çeşitli ayinlerde ve mitlerde kendisini korumuştur. Yumurtanın köşesiz ve çıkıntısız yapısı, aynı zamanda canlı taşıma özelliğine sahip olması, onu muhtelif törenlerin başaktörü yapmıştır. Yumurta, hamile kalmak isteyen kadının başvurduğu doğal kaynaklardan biridir. O, aynı zamanda gebe bir kadının yemesi/yememesi gereken bir besin, kırklı bebeğe verilen ilk hediye; kırk çıkarılırken ve "kırk basması"

Geliş tarihi (Received): 09.10.2020 - Kabul tarihi (Accepted): 23.03.2021

* Bu araştırma, 218K187 numaralı "Ritüelleri ve Anlatılarıyla Siirt, Diyarbakır ve Mardin'de Kutsal Mekânlar: Dinî, Tarihî, Kültürel ve Edebî Doku” adı TUBİTAK projesinden üretilmiştir. Siirt Üniversitesi Etik Kurulu'nun 18/09/2018 tarih ve 15 sayılı oturumunda araştırmanın etiksel uygunluğu onaylanmıştır.

** Prof.Dr., Siirt Üniversitesi Eğitim Fakültesi Türkçe ve Sosyal Bilimler Eğitimi. (Siirt University Faculty of Education Turkish and Social Sciences Education) rezankarakas@hotmail.com. ORCID.0000-0001-9138-3825 
rahatsızlığı tedavi edilirken kullanılan bir araç olarak da kültürel yaşantıdaki yerini alır. Yeni gelin, yaşayacağı eve adım atarken eline aldığı yumurtayı dış kapının başına firlatır. Gelin ve damat düğün günü yumurta yer. Türk halk kültüründeki pratiklerde birden fazla işleviyle eşsiz bir görünüm sunan yumurta; sarısı, ak1, kabuğu veya rengi ile ası1/yan unsur olarak işlev görür.

Anahtar sözcükler: yumurta, Türk halk kültürü, geçiş dönemleri, inanış, ritüel, lohusa kadın

\begin{abstract}
Egg appears in many narratives in Turkish and world mythologies in events related to the creation of the world, gods, demigods and human beings or the birth of heroes. The symbolic meaning of the egg has preserved itself in various rites and myths since prehistoric times. The fact that the egg has no corners and protrusions, as well as the ability to carry live, has made it the leading actor of various ceremonies. Egg is one of the natural resources used by women who want to become pregnant. It is also a food that a pregnant woman should/should not eat, the first gift given to a baby in her forties; it takes its place in cultural life as a tool used when removing forty and treating forty flushes. As the new bride steps into the house where she will live, she throws the egg she has picked up at the entrance door. The bride and groom eat eggs on the wedding day. Egg that offers a unique appearance with its multiple functions in practices in Turkish folk culture; it functions as the main/side element with its yellow, flux, shell or color.
\end{abstract}

Keywords: egg, Turkish folk culture, transition periods, belief, ritual, forties woman

\title{
Extended summary
}

In this work, the appearance of egg in both mythical world and daily life has been analysed. In some of the mythical narratives, the creation of sky and earth is based on the egg. When narrating the births of gods or demigods, references are made to the egg from time to time. Egg which is the extraordinary being of mythical world, has preserved this special position in the daily life of both the world and Turkish people from past to present. Therefore, in the research, although the egg figures used in the transitional periods of various world people are also included, the rituals and various beliefs carried out in the context of "egg", especially in the transition periods of Turkish folk culture, are examined.

Generally in Turkish society, whether a family has a child or not is an important issue. Especially in families that have no child in rural societies, the responsibility of this negative and undesirable situation often attributed to women. Therefore, a woman applies to various ways in order to get the ability to give birth. The first adventure of egg with human being appears in the practices carried out by the woman who wants to gain the experience of giving 
birth to realize this desire. In these practises, egg is applied to genital or waist of the woman, who wants to be pregnant, by being blended with some herbal/animal products that have gained "healing" qualities in folk culture. There are some other methods applied by woman in this context. One of these methods is to set out to sacred place. The woman, who puts egg to that kind of place, transmits her wish for a child to the owner of this sacred place. The egg which is left as a "votive" to the Vahit Baba Fountain in Diyarbakır functions as a seed by being blended with the "water" that has a healing quality in itself. The woman from Cizre, who walks door to door with the egg she holds on the day of Ashura, expresses her desire for a child.

The relationship between a woman and egg during pregnancy continues in a positive and a negative way. In some regions, egg is thought to be in foods that must be avoided by future mother during pregnancy. In some regions, on the other hand pregnant woman is advised to eat egg. It has been assumed that by that kind of advises, the positive power of egg will be utilized. In the examples that eggs are recommended to be eaten during pregnancy, the "similarity" connection between the white part of egg and coming child's being white or beautiful. In addition to all of these, it has been benefited from egg in the determination of baby's sex by "fortune telling" practice.

For the next forty days after giving birth, egg is used both to feed the mother, to protect her from evil eye and physical illnesses and to prevent every kind of evil that may affect the baby. During this period, there are such practices like giving egg to puerperant as a gift, applying to mother's body by mixing different substances, hanging to the room of mother or baby or rolling in the baby's bed. Egg which is one of the symbols in postnatal practices is also used in "making the forties" ceremony. In the "farewell to making the forties" ritual, actual factor egg is presented to baby with wishes for "wealth, blessing" and act of kindness. Egg is applied from time to time in practices for a baby's being weaned, first step, first tooth or circumcised boy.

It is seen that egg is used functionally in marriage ceremony, which is the second of all transition periods, in Turkish folk culture. "Productivity" is wished in some practices like throwing egg to top of the door, make groom and bride eat egg, cracking egg above groom's head etc.; it is wanted to benefit from functional and symbolic power of egg.

The connection of egg with death period is that it is a "saçı (benefaction)" presented to the dead. Another different important issue is that the shells of egg which are used as a nutritious element in daily life are cut into pieces before being thrown away with the concern that devil will harm their belief by giving information about pouring water with eggshell.

With all these data, we can say the following about the function of egg in the transition of Turkish folk culture:

1.Egg is one of the sources to which a woman apply in order to give birth from past to present.

2.Egg is used for determining sex by means of fortune telling.

3.The pregnant woman's egg eating affects baby's physical and mental properties negatively or positively. 
4.Egg is equipped to protect puerperant woman and kırklı baby (forty days old baby) from all kinds of evil.

5.A puerperant woman's coming across with a hen that has incubated is an unwanted situation.

6.It is possible to "making the forties" of a baby thanks to egg. Especially for the "farewell to making the forties" event, the main element is egg.

7.Egg is used in ceremonies for a baby's being weaned, first step, first tooth.

8.The quality of egg that helps woman to give birth makes it a main factor of wedding ceremonies. For this reason, bride and groom either eat or crack an egg in their wedding.

9.For not losing belief at the time of death, it is necessary to cut into pieces and throw away the shells of egg that is used for its nutritious qualities in daily life.

In some parts of myths, there are emphasises on the hatching of some gods/ demigods, as well as the creation of the earth and heaven by means of egg. There are some narratives that based the creation of first human and the animal on egg. In some cultural frames, eggs are valued as gifts to gods and living/dead people.

The cultural memories of community from myths to today are beautified with belief and practices towards ostrich, duck, stork, chicken and ant eggs. In wedding ceremonies, egg is used in practices for bride's and groom's for the purpose increasing man's potency and woman's fertility. When there is a lack of child, magical power of egg is used in maximum; eggs are used both in sacred place centred treatments and in the mixtures of folk midwives. In the egg's contacts in relation to death, the symbol of "resurrection" for the other life is envisioned.

\section{Giriş}

Mitik dönemlerden günümüze doğadaki canlı ve cansız unsurlar, kendisini ve yaşamı anlamak isteyen insanoğlu için önemli anlamsal değerlere sahip olmuştur. İnsan nesli; kendi varoluşunu tamamlamak, yenilenmek, güçlenmek gibi kaygılarla bu doğaüstü varlıklarla adeta savaşmış, zaman zaman da anlaşmalar yapmıştır. Dağ, taş, demir, ateş, su, toprak ve daha nice varlık, bu kapsamda insanın ilgi odağı olmuştur. Sıra dışı davranışları ve fiziksel özellikleri ile yılan, kartal, kurt başta olmak üzere birçok hayvan ve hayvansal ürünler de insanoğlunun anlam arayışlarını mitik anlatmalarla besleyerek desteklemiştir.

Hayvansal bir ürün olan yumurta, dünyanın varoluşunun anlatıldığ 1 mitlerde yaşamı var eden gizil bir güç olarak ortaya çıkar. Mitolojilerde yumurtaya yönelik birçok anlatı mevcuttur:

\footnotetext{
"Mısır mitolojisinde başlangıçta uçsuz bucaksız bir bataklık ve bu bataklıkta da bir yumurta vardır, dünyayı yaratan tanrı Ra, bu yumurtadan çıkar ve uçmaya başlar. Japon mitolojisinde evren başlangıçta bir yumurtadır, ilk üç tanrıyla gökyüzü ve yeryüzü, bu yumurtadan doğarlar. Mısır mitolojisinde ayrıca Osiris yumurtası ünlüdür, efsaneye göre bu yumurtaya Osiris on iki kara ehram ve Seth on iki ak ehram sığdırmıştır” (Hançerlioğlu, 2010: 565).
} 
Taocu geleneğe göre "soluk alıp verme” birbiriyle birleşmiş ve bir yumurtayı, Ulu Bir'i oluşturmuştur; daha sonra bundan yer ve gök çıkmıştır (Eliade, 2009: 404). Hint mitolojisinde dünya, bir yumurta sayesinde var olmuştur. "Kalevala destanının başlangıç epizotunda kozmik yumurta ile evrenin yaratılışı ve ilk insanın dünyaya gelişi anlatılmaktadır” (Abdürrezzak, 2019: 235). Kozmik yumurtanın kabuğu, uzayın dünya çerçevesidir, içindeki bereketli tohum gücüyse doğanın tükenmez yaşam dinamizmini örnekler (Campbell, 2010: 308). Maorilerin anlattığı öyküye göre bir kuşun ilksel denize düşürdüğü yumurtadan bir erkek, bir kadın, oğlan, kız, domuz, köpek ve kano çıkmıştır. Yumurtadan çıkan insan ve hayvanlar kanoya binerek Yeni Zelanda'ya kürek çekmişlerdir (Campbell, 2010: 323). Orfizm denilen ve şair Orpheus'tan geldiği ileri sürülen mistik akımda Eros'un dünyayla birlikte kaostan çıktığına yahut da Gece'den doğma evren yumurtası ikiye bölünüp yarı kabuğundan gök, yarı kabuğundan toprak oluştuğunda doğduğuna inanılır (Erhat, 2013: 106). Antik Çağ felsefesinde doğanın dölleyici ilkesine 'Orpheus'un yumurtası' denir, Orfiklere göre toprak ana Kybele bir yumurtadan doğar (Hançerlioğlu, 2010: 565).

“Okyanusya'da insanın bir yumurtadan doğduğuna inanılır. Yeni yıl ağaçları olarak adlandırılan mayıs ağaçları, Aziz Yuhanna ağacı vb. yumurta veya yumurta kabuklarıyla süslenir. İran'da renkli yumurtalar, özel yeni yıl hediyeleridir. Balkan ülkelerinde paskalyada dağıtılan kırmızı yumurtalar da benzer dinsel törenlerin parçasıdır ve amaç, baharın gelişini kutlamaktır. Hinduların Holi Bayramı boyunca bazı bölgelerde ateş yakma, Kâmadeva’yı ve Rati'yi temsil eden erkek ve kadın biçiminde iki küçük heykeli ateşe atma âdeti vardır; ilk heykel ateşe atılırken bir yumurta ve canlı bir tavuk da beraberinde atılır" (Eliade, 2009: 395).

Samruk kuşu, her yıl Bayterek adlı yaşam ağacının tepesine altın bir yumurta bırakır. Ancak ağacın kökleri arasında yaşayan ejderha, yukarı tırmanarak bu yumurtayı yer. Yer altı krallığına ulaşan Kazak halk kahramanı Er Töştik, bu ejderhayı öldürür. Er Töştik, bu kuşun yardımıyla yer üstüne çıkar (Ur15, Ur16). Kartal, güneş ve ay; göğe çıkıp şamanların ülkesindeki kutsal bir ağacın dalına bir yumurta bırakır. Kartal kuluçkaya oturur; yumurtadan yavru çıkar ve bu yavru şaman olur (Kim, 1979: 22, 23, Akt: Kim, 2004: 50). Newal'in verdiği bilgilere göre; Mısır mitolojisinde erken dönem yaradılış efsanelerinde yumurta sıklıkla Güneş'le ilişkilidir. O, aynı zamanda saflığı temsil eder. Her şeyin sudan ibaret olduğu kaos ortamından Mısır'daki birçok tanrı ile Viraj, Prajapati, Brahma gibi diğer kutsal varlıklar tarafından temsil edilen üreme arzusu ortaya çıkar. Newal, Sovyetler Birliği'nde dinsel ve geleneksel uygulamaların azaldığını, Ortodoks takviminde dinsel bir festival olan paskalyanın da 1 Mayıs gibi din dışı bir yapıya dönüşmüş olduğunu belirttikten sonra paskalya yumurtasının da neredeyse kaybolduğunu; tahta, cam veya porselenden yapılan yumurtalara nadiren ancak antika dükkânlarında rastlandığını sözlerine ekler. O, sanatçıların tamamının paskalya yumurtasının kökeninin bahar festivali, yeniden doğuş ve doğurganlıkla ilgili bir pagan festivaline dayandığını belirttiklerini dile getirir (Newal, 1967: 6-29).

Green (2006), çalışmasında geçmişten günümüze deve kuşu yumurtasının Hristiyanlık ve Müslümanlıktaki anlamsal boyutlarını gözler önüne sererek hem kiliselere hem de 
türbelere asılan deve kuşu yumurtasını ele almıştır. O, aynı zamanda deve kuşu yumurtasının masumiyetle ilişkili olduğuna Akdeniz'de kötülüğe karşı koruyucu olarak kullanıldığına, Anadolu'da kötülüğü önleme gücünün yanı sıra örümceklerden gelecek zararı da ortadan kaldırdığına, Fas’ta ise hastalığı tedavi etmek için hazırlanan ilaçlarda yer aldığına vurgu yapmiştır.

Karakalpak Türklerinde Nevruz Bayramı'nda yapılan “sümelek” yemeğini pişirmeden önce kazanda yumurta kızartılır. Yumurta, yeni hayat ve başlangıç sembolüdür. Karakalpakistan'da Mizdahkan Kalesi'nde Cümart Kassap Tepesinde bulunan altı tane su kabının her birinin içinde üçer tane olmak üzere toplam on sekiz yumurta bulunmuştur. Yumurtaların bulunduğu yer, çocuk mezarı sayılmaktadır. Yumurtaların kız ya da erkek çocuk sayısını gösterdiği düşünülmektedir (Hojaniyazov, 1989, Akt.: Madiyarova, 2017: 39).

Moluk Adaları'nda hasta kişinin ruhunun cinler tarafından çalındığına inanılır. Ruhu geri almak için cinin yaşadığı yere birçok sunu ile birlikte yumurta bırakılır. Ayrıca Celebesli Alfoerler yeni bir eve girdikleri zaman ev halkının ruhları yenilenir; gece yapılan törenin ardından sabahleyin tanrılara yumurta ve pirinç sunulur (Frazer, 2017: 88, 89). Meksika'da (Url 3) göz değmesine uğrayan kişinin üzerindeki negatif enerjiyi almak için canlı hücre olarak bilinen yumurta kullanılır. Uygulamada kişinin başı üzerinde gezdirilen yumurta, bir saçı objesidir. Hastalığın teşhis ve tedavisinden sonra yumurta bir bardak içinde kırılır ve "okuma" işlemi yapılır. Cuernavaca yakınındaki bir kasabada halk hekimi olarak bilinen Don Ricardo, 2003 yılında New Mexico Üniversitesinden gelen Amerikalı öğrencilere bu ritüeli göstermiştir. Orta ve Doğu Ukrayna'da (Url 2) halk tıbbında bir materyal olarak kullanılan yumurta, hastanın vücudunun belirli yerlerinde daireler çizilip gezdirildikten sonra su dolu bir bardak içerisine kırılır. Uygulama, üç yumurta ile üç kez devam ettirilir.

Yumurta, hem insan hem de tarımla ilgili bereket törenlerinde dikkat çekici bir figürdür. 17. yüzyılda Fransa'da gelinin doğurganlık potansiyeli kazanması için yeni evine girerken yumurta kırması gerekirdi. Almanlar ve Slavlar arasında ürünün verimli olması için paskalya öncesi perşembe günü sabanın üzerine yumurta, ekmek ve undan bir karışım sürülürdü (Leach, 1950: 341). Birçok kültürde yumurtanın erkeklerin cinsel gücünü, kadınların doğurganlığını arttıran bir varlık (Newal, 1971: 113-141) olduğu dile getirilir. Öte yandan "Asyalı Hintli kadınlarda hamilelik döneminde yumurta; düşük riskini azaltmak ve vücudun dengesini korumak için fındık, biber, sarımsak, mango ve zencefille birlikte kaçınılması gereken sıcak yiyecekler arasında sayılır” (Goyal, 2016). Hmonglarda yumurta, uğur uğursuzluğun tespiti ve kehanette bulunmak amaciyla parçalara ayrılıp incelenebilir (Tapp, 1989: 70). Çin kültüründe (Cheah, 1998, Akt.: Rosmaliza, 2013: 269) bir düğündeki kırmızı yumurtalar, doğurganlığ1 ve verimliliği sembolize eder. Cava düğününde (Url 1) gelin ve damat, üç defa sağ elleriyle çeşitli yiyeceklerle birbirlerini beslerler. Bunlar arasında yağda pişirilmiş yumurta da bulunur. "Malay düğün törenlerinde geleneksel yapraklar ve baharatlarla karıştırılmış su içinde birkaç saat boyunca kaynayan yumurtalar "hediyelik" olarak hazırlanır" (Muhammad, 2013: 273).

Rusya'da salı günü kutlanan Aziz Thomas Haftası'nda, akrabalar dinî törenlerini ağıt yakarak, ziyafet vererek sürdürür ve ölüye hediye amaçlı yumurtalar bırakırlar (Ivanits, 1989: 
9). Filipinler'de (Magat, 2002: 71) döllenmiş ördek yumurtası; sadece beslenme ihtiyacını karşılamakla kalmaz, aynı zamanda tanrıya adama, ölüyü onurlandırma gibi amaçlarla da kullanılır. Ritüellerde kırılan yumurtalar sayesinde verilen sözler yinelenir.

Görüldüğü üzere tarih öncesinden bu yana yumurta, bireyin protein ihtiyacinı karşılamakla kalmamış, aynı zamanda niteliği ve işlevselliği ile insan hayatının farklı aşamalarında önemli görevler üstlenmiştir. Türk halk kültüründe yumurtaya dair birçok inanış ve uygulama bulunmaktadır. Bunları aşağıdaki başlıklar hâlinde sınıflandırmak mümkündür: 1. Geçiş dönemlerinde yumurta 2. Halk inanışı bağlamında yumurta 3. Halk hekimliği uygulamalarında yumurta 4. Kutsal mekân ziyaretlerinde yumurta 5. Bereket törenlerinde yumurta 6. Özel günlerde yumurta (bahar bayramları vb.).

Bu çalışmada sadece yumurtanın Türk halk kültüründe "geçiş dönemleri” ile ilişkili kullanımı irdelenecektir. Geçiş dönemi uygulamaları arasında halk hekimliği ve kutsal mekân ziyaretleriyle ilgili olanlar da bulunmaktadır. Ayrıca "doğum, evlenme, ölüm” gibi geçiş dönemlerinde yapılan hemen her uygulama, "inanış" sarmalının etkisi altındadır. Bazı özel günlerde yapılan uygulamalarda dahi geçiş dönemlerinden birine gönderme söz konusu olabilmektedir. Bu yüzden yumurta ve geçiş dönemleri arasındaki ilişki; halk hekimliği ile kutsal mekân ziyaretleri gibi unsurlarla kesişen geçiş dönemi ritüelleri de dikkate alınarak irdelenmiştir.

\section{Türk halk kültürüi geçiş dönemlerinde yumurta}

Türk halk kültüründe doğum, evlenme ve ölüm ana başl1klarının genel ifadesi olan "geçiş dönemleri” kapsamında bir dizi uygulama mevcuttur. Hac, askerlik, sünnet gibi ara geçiş dönemleriyle bu uygulamaların sınırları bir hayli genişler. Tüm bunlarda "yumurta"nın çoğu kez işlevsel ve anlamlı olarak kullanılması oldukça dikkat çekicidir. Henüz bir çocuğa sahip olunmadan başlanan ve ölüm sonrasına uzanan pratiklerde yumurta, adeta bir filmin başrol oyuncusu görevini üstlenir. Gözlem, görüşme ve doküman analizi yöntemleriyle elde edilen verilerin terkibinden ve yorumundan oluşan bu çalışmayla yumurtanın Türk halk kültüründe geçiş dönemlerindeki durumunun ayrıntılı tasnifi ve analizi yapılmıştır.

\section{Doğum ve yumurta}

Hayatın ilk geçiş dönemi olan doğum, Türk halk kültüründe “doğum öncesi, doğum anı ve doğum sonrası” gibi üç farklı grupta inanış ve ritüellere sahne olur. Bütün bu süreçlerde "anne ve bebek" bazen birlikte bazen de ayrı ayrı koruma altına alınır. Türk halkları arasında doğuma dair uygulamalarda ortak unsurlar bulunduğu gibi bölgeden bölgeye farklılıklar da görülür. "Yumurta" bağlamında da durum değişmez. Doğum sürecinde faydalanılan varlıklardan biri olarak karşımıza çıkan yumurta, bazen tek başına bazen de diğer sembolik varlıklarla etkileşime girerek ritüellerdeki yerini alır. Anne olma arzusunun bir sonucu olan ve geleneksel yaşamda benimsenen uygulamalarda yumurtanın “üretkenliği arttırıcı” yönüne vurgu yapilır. 


\section{Hamilelik öncesinde yumurta}

Hamile kalmak için yapılan uygulamaların bir kısmında yumurtadan istifade edilir. Anadolu'da hamile kalmak için yapılan uygulamalarda yumurtanın bilhassa maydanoz, soğan ve bal gibi bitkisel/hayvansal unsurlarla karıştırılarak macun haline getirilmesi ve elde edilen içeriğin anne olma isteği duyan kadının beline veya cinsel organına sürülmesi söz konusudur:

Mersin'de maydanoz ve soğan, zeytinyağında kavrulup üzerine yumurta kırılır; kayısı kıvamına gelen bu karışım, bir tülbent üzerine konularak adet gününden hemen sonra kadının cinsel organına sarılır. Bu uygulama üç gün üst üste gerçekleştirilir (Çıblak, 2011: 3). Tunceli merkezde ve Elazığ'ın Baskil ilçesinde yumurta ve kireç karıştırılıp bele sürülür (Parlayan, 2012: 9; Kıyak, 2005: 20). Zile'de çocuğu olmayan kadın, hamama götürülür; kadının beline yumurta, kireç, bal ve sındık denilen baharat karışımından sürülerek yakı yapılır (Sezmiş, 2018: 34). Tunceli'den göçen ve Elâzı̆̆g'da yaşayan Alevilerde yumurta ve keçi kılının dövülmesiyle meydana getirilen karışım, çocuk sahibi olmak isteyen kadının karnına sürülür (G. Küçük, 2012: 22).

Döl yatağının açılması için kara bir tavuğun yumurtasının sarısı, üzerine karabiber ekildikten sonra sıcak temiz bir beze sarılıp dölyatağına sokulur (Boratav, 1994: 144-145). Erzurum'da (Açar, 2015: 54) keten tohumu ile pişirilen ve bir tezeğin üzerine dökülen yumurta üzerine, hamile kalmak isteyen kadın oturtulur. Kadının hamile kalabilmesi ile yediği yiyecekler arasında ilişki kurulur. Bu yüzden "Erzincan'da yumurta, Ordu'da ise yumurtanın akı 49 gün içilir (Örnek, 1979: 44, 45).

Yumurtaya, büyüsel halk hekimliği uygulamalarında da rastlanır:

“İstanbul'un Şile ilçesinde bulunan Sortullu türbesini özellikle çocuk sahibi olmak isteyen karı koca, ziyaret eder ve her biri kendi adına sandukanın içine bir adet çiğ yumurta koyar. Yumurtalar bir gece sandukanın içinde kalır. Ertesi gün türbede bulunan zat, hangi yumurtaya yazmış, yani bir işaret vermişse o kişinin kusurlu olmadığına inanılır. Bu durumda yumurtası yazılmayan kişi kusurlu kabul edilir. Kusurlu kişi, yazılı yumurtayı yiyerek kendisini tedavi eder. $\mathrm{Bu}$ işlemin Hıdırellez'den on beş gün önce yapılması gerekir” (Gider, 2009: 100).

Şırnak'ın Cizre ilçesinde çocuk sahibi olmak isteyen kadınlar; aşure gününde kara çarşaf giyer, ellerine yumurta veya hurma alarak kapı kapı dolaşırlar (K8, K9). Hamile kalmak isteyen kadın, leylek yumurtasıyla hazırladığı pekmezli yumurtayı yer. Aynı zamanda leylek yumurtası kabuğuyla kırk kez doldurduğu bir miktar suyu başına döker (Karakaş, 2020: 21). Diyarbakır'ın Ergani ilçesinde Vahit Baba Çeşmesi'nin suyundan içilerek ve çeşme taşına da para ve yumurta bırakılarak çocuk istenir; aynı zamanda "Sıcakpınar" adı verilen suya “doğurganlığın sembolü” olan yumurtalar bırakılır (Demir, 2006: 27; Yavuz, 2007: 209; Uçak, 2007: 21, 51).

Siirt'te rüyasında yumurta gören kişinin çocuğu olur (K26). "Karakalpak Türk kadınları da rüyada yumurta görmeyi hamile kalmaya yorumlar" (Hojaniyazov, 1989, Akt.: Madiyarova, 2017: 38). Yumurtanın doğurganlık ve üretkenlikle olan ilgisi, Siirt’te 
geçmiş yıllarda kutlanan Şıhrı'l Bayf adı verilen etkinlikte de açıkça görülür. Şıhrı'l Bayf’ta nişanlı erkeğin ailesi, nişanlı kızın ailesine 100-500 civarında boyanmış yumurta gönderirdi. Kızlarını daha önceki yıllarda evlendirmiş olan aileler de damat tarafina yumurta yollardı. Kutlamaya özellikle nişanlı çiftler götürülürdü. Yumurta hediyesi, evlenmesi muhtemel çiftlerden -her ne kadar açıkça belirtilmese de- doğadakine benzer şekilde üreme, çoğalma ve canlanma talep edildiğinin göstergesidir (Karakaş, 2020: 261).

Görüldüğü üzere, Türk halk kültüründe anne olmak isteyen kadın, yumurtadan çeşitli vesilelerle istifade etmektedir. Uygulamalarda yumurtanın farklı bileşenlerle bir araya geldiği görülür. Elde edilen karışım; doğurma yetisi kazanmak isteyen kadının cinsel organı, karnı veya beline sürülerek tedavi gerçekleştirilir. Kutsal mekân ziyaretleriyle kesişen uygulamalarda ise yumurtanın daha çok simgesel gücünden yararlanılmakta ve büyüsel yollu sağaltma işlevine başvurulmaktadır. Bu tarz pratiklerde yumurta, bir saçı ve adak nesnesi olarak kullanılmaktadır.

\section{Hamilelik döneminde yumurta}

Türk halk kültüründe bir kadının hamile kalmasıyla doğum sürecindeki uygulamalar bitmez; aksine artarak ve yoğunlaşarak devam eder. Çünkü hamilelik dönemi tehlikelerle dolu dokuz ay devam eden uzun bir yolculuktur. Kadın ve bebeğin birlikte çıktıkları bu yolculukta anne adayı, adeta bir kaptan görevindedir. Bebeğin güven içinde gelişimini tamamlaması, herhangi bir dış etkenden gelecek zarardan korunması için anne adayının yediği, içtiği, baktığ1 ve dokunduğu şeylere azami seviyede özen göstermesi gerekir.

Bir anne adayının yediği yiyeceklerin bebek üzerinde olumlu veya olumsuz etkisi olduğuna inanılır. Anneden aldığı besinlerle büyüyen bir bebeğin annenin yediği veya yemediği yiyeceklerden etkilendiği düşünülür. Türk halk kültüründe bu hususta hayvansal veya bitkisel ürünlerle ilgili birçok inanış bulunur. Bu bağlamda bazı yörelerde yumurta, hamilelik döneminde anne adayının uzak durması gereken yiyecekler arasında gösterilir. Örneğin Konya'nın Bozkır ilçesinde çocuğun saçının çıkmayacağına inanıldığı için hamile kadına yumurta yedirilmez (Kabak, 2011: 22). Ayrıca hamileyken yumurta yiyen kadının çocuğunun haylaz olacağına inanılır (Kabak, 2011: 28). Elazığ'da yaşayan Zazalarda ve Suruç'ta (Atmaca, 2006: 23; Kahraman, 2010: 14) hamile kadının yumurta içmesi ile çocuğun yumurta gibi olması arasında ilişki kurulur.

Bazı bölgelerde ise hamile kadına yumurta yemesi hususunda tavsiyelerde bulunulur. $\mathrm{Bu}$ tür telkinlerde yumurtanın olumlu gücünden istifade edileceği varsayılır. Hamilelik sürecinde yumurta yenilmesinin önerildiği örneklerde yumurtanın beyazı ile doğacak çocuğun beyaz veya güzel olması arasında “benzerlik” ilişkisi kurulur. Zile ilçesine bağlı Yalnızköy'de (Sezmiş, 2018: 38) çocuğun beyaz olması için yumurtanın beyazı; Erzincan'ın Kemaliye ilçesinde (Yıldırım, 2013: 9) ise gamzeli olması için yumurta yenir. Kastamonu'nun Tosya ilçesinde hamile kadının yumurta yediği takdirde, doğacak bebeğin güzel olacağına inanılır (Karabüber, 2017: 46). Kuzey Kıbrıs Türk Cumhuriyeti'nde aşeren kadının kendi eliyle pişirdiği yumurtayı yemesi durumunda bebeğinin güzel olacağına inanılır (Balcı, 2019: 63). 
Çorum'un Bayat ilçesinde yumurta yiyen kadının bebeğinin yüzünün oval olacağı söylenir (Örnek, 1979: 88).

Hamile kadının yumurtaya temas etmesinin doğacak bebeğin fiziksel özelliklerini etkilediği varsayılır: Tekirdağ'da doğacak bebeğin güzel olması için anne adayı, yumurta üstüne oturtulur (Artun, 1998: 4). Van'da bebeğinin gamzeli olması için hamile kadının kuşağının arasına yumurta koyması tavsiye edilir (K24). Denizli'nin Çameli ilçesinin Elmalı köyünde yumurta kabuğunu tepeleyen hamile kadının bebeğinin doğar doğmaz öleceğine inanılır (Çelebi, 2017: 222).

Hamilelik sürecinde bebeğin cinsiyetinin tespitine yönelik yapılan bir çeşit fal uygulamasında da yumurta dikkati çeker. Kayseri’nin Pınarbaşı, Sivas'ın Ulaş ilçelerinde; Erzurum, Siirt, Mardin ve Diyarbakır'da doğacak bebeğin niyetine (Aslan, 2011: 39; Kılıç, 2012: 9; Açar, 2015: 60; K1, K2, K3) haşlanmış bir yumurta; gebenin saç teli, ip veya elle ortadan ikiye ayrılır. Yumurtanın sarısına bakılır, yumurtanın sarısı çukursa kız; dolgunsa erkek çocuk olarak yorumlanır. Ayrıca, Erzurum'da (Açar, 2015: 60) haşlanan yumurta gebeye gösterilir. Bu esnada kadının burnunu tutması, erkek çocuk; ağzını tutması kız çocuk ile özdeşleştirilir.

Hayatın ilk geçiş dönemi olan doğum sürecinde hem bebeği hem de anneyi görünen/ görünmeyen tehlikelerden korumak gerektiğine inanılır. Bu bağlamda halk arasında alınan birçok tedbir vardır. Bunlar arasında yumurtayla ilgili bir uygulamaya Erzurum'da rastlanır: "Doğumu kolaylaştırmak için gebenin evine bacadan aşağı yazılı yumurta sarkıtılır" (Açar, 2015: 6).

\section{Doğum sonrasında yumurta}

Doğum sonrası özellikle ilk 40 günlük süre anne ve bebek için tehlikelerle doludur. Bu tehlikeler; nazar, cin çarpması gibi vakalardan mürekkeptir. Diyarbakır'da "lohusanın kazma küreğinin sırtında" olduğu şeklindeki ifade de annenin başına gelebilecek olumsuzlukları çarpıcı bir şekilde özetler. Kadına doğurma yetisi kazandıran, cinsiyet tayininde kullanılan ve aynı zamanda doğumu kolaylaştıran potansiyel bir güce sahip olan yumurta, doğumdan sonra anne ve bebeği korumak için de görevini sürdürür. Doğum sonrası lohusa için tereyağında pişirilen yumurtanın üzerine pekmez dökülmesiyle elde edilen "pekmezli yumurta" veya "kaygana" adı verilen bir tür tatlı hazırlanır. Burada yumurta, "inanış" yönüyle değil besin kaynağı vasfiyla ön plana çıkar.

Yumurta, lohusayı ve bebeği nazardan korumak için kullanılır. Örneğin Azerbaycan'da kırklı bebeğin yalnız kalması durumunda eve çarşaf asılır ve ortasına pişmemiş yumurta konur. Canlı olan yumurtanın evdeki kötü güçlere karşı koruyucu olduğuna inanılır (Najafov, 2019: 41). Kastamonu, Manavgat ve Merzifon'da (Boratav, 1994: 121; Şimşek, 2013: 269; Serdaroğlu, 2018: 24) lohusayı ve çocuğu korumak için odanın herhangi bir yerine asılan nesnelerden biri de yumurtadır. Ermenilerde de benzer bir durum vardır. Onlar da "doğum yapmış kadınların ve bebeklerin yataklarının yanına yumurta asar ve suya iki-üç tane yumurta atıp o suyu doğum yapan kadının yanına koyarlar” (Çursin, 1929, Akt.: Mayidarova, 2017: 
39). Erzincan'ın Kemaliye, Ankara'nın Nallıhan ilçelerinde ve Elazı̆̆' da doğum yapan kadına getirilen yiyecekler arasında yumurta bulunur (Kahraman, 2010: 15; Yıldırım, 2013: 13, K17). Van'da yeni doğan bebeğin kundağının içine ekmek ve yumurta konulur; böylece bebeğin rızkının bol olacağına inanılır (K24). Bursa' da kırk uçurma zamanında ailenin yakınları veya annenin arkadaşları tarafından bebeğe yumurta sepeti getirilir. Fiyonk ve kurdelelerle süslü sepetin içerisine renk renk boyanmış yumurtalar konur. Bebeğin güzel olması temennisiyle yapılan bu uygulama, anne kırk uçurma ziyaretine gittiğinde de yapılabilir (K13). Midyat'ta bebeğin yaşaması, ömrünün uzun olması ve talihli olması için un dolu bir tas üzerine üç, beş veya yedi yumurta birakılarak birine verilir (Uygur, 2008: 27, 43). Bitlis'te yeni doğan bir bebeğin doğumunun yirminci gününde komşulara yumurta dağıtılır. Böylece bebeğin tok gözlü olacağına inanılır (K25).

Yumurta, doğumdan sonraki süreçte lohusayı bedensel rahatsızlıklardan korumak için de kullanılır. Mesela “Elazığ’ da doğum yapan anne üşütmesin diye yumurta kırılıp içine zencefil serpilir; bu karışım bir beze konarak hazneye yerleştirilir (Tanyıldızı, 2015: 1078). Elazı ̆̆' da ve Şanlıurfa'nın Suruç ilçesinde doğum olayının 15. gününde lohusa, hamama götürülür. Bir kap içinde kırılan yumurta, tuzla karıştırılarak lohusanın bütün vücuduna sürülür (Atmaca, 2006: 26; Kahraman, 2010: 19).

Tokat'ta yaşayan Karaçaylar, çocuğu beşiğe koymadan önce beşiğin içinde yumurta yuvarlarlar (Çinpolat, 2009: 39). Bebeğin beşiğe yatırılmadan önce onun yerine yuvarlatılan yumurta, burada adeta çocuğun yerini almaktadır. "Diyarbakır'ın Bismil ile Tokat'ın Zile ilçelerinde yeni doğan bebeğe ileriki yaşamında tüylü olmasın diye karınca yumurtası sürülür" (K16; Sezmiş, 2018: 40).

Doğum sonrası uygulamalarda yumurta, bir yandan anneyi beslemek, bedensel rahatsızlıklardan ve nazardan korumak bir yandan da bebeğe gelebilecek her türlü kötülüğü önlemek için kullanılır. Bu süreçte yumurtanın lohusaya hediye edilmesi, farklı maddelerle karıştırılarak annenin vücuduna sürülmesi, bebeğin ve annenin bulunduğu odaya asılması veya beşikte yuvarlatılması gibi uygulamalar söz konusudur.

Lohusalık dönemindeki bir kadının kuluçkaya yatmış bir tavukla karşılaşma yasağı bulunmaktadır. Diyarbakır'da lohusaların kuluçkaya yatmış bir tavuğun yanına gitmelerinin tavuk yumurtalarına zarar vereceğine inanılır (K4, K5, K6). Doğum yapan bir kadının sesi, kuluçkaya yatmış bir tavuğa giderse kuluçkadaki yumurtalar çatlar ve bunlardan civciv çıkmaz (Karakaş, 2020: 209). Azerbaycan'da (Najafov, 2019: 41) kırklı bebeğin bulunduğu bir eve yumurta girmeden evvel bebeğin odadan çıkarılması gerekir. Yumurta içeri alındıktan sonra bebek tekrar odasına götürülür. Aksi hâlde bebeği kırk basar. Lohusanın kuluçkaya yatmış tavukla, kırklı bebeğin yumurtayla karşılaşmasından duyulan endişe ve korku; üretken, canlı taşıyan varlıkların birbirini olumsuz yönde etkileyeceği endişesinden kaynaklanmış olmalıdır. Burada aynı zamanda yumurtanın çocuğa, tavuğun da kadına eş tutulduğu dikkati çekmektedir. 


\title{
"Kırk çıkarma" ve "kırk uçurma" ritüelleri ile "kırk basması" rahatsızlığının tedavisinde yumurta
}

Doğum sonrası "kırk çıkarma" veya "kırk uçurma" uygulamalarındaki simge varlıklardan biri de yumurtadır. Bunlar arasında en dikkat çekici olan, kırkı çıktığı için ilk gezmesine götürülen bebeğe ev sahibi aile tarafından yumurta verilmesidir. Yöreden yöreye yumurtaya bazen ekmek veya şeker de eşlik eder. Burada yumurta; bolluk, bereket ve iyi niyet temennisinin bir ifadesi olmalıdır.

\begin{abstract}
“Kastamonu'nun Tosya ilçesinde lohusa, kırkı çıktığında kırk uçurmaya gittiği yerden dönerken bebeğin koynuna yumurta, ekmek veya şeker konur. Bebeğin kısmetiyle gideceğine inanılır. Tosya'da ayrıca kırkı çıkan ve ilk gezmesine giden bebeğin kundağına dönüşte kömür, bir yumurta ve bir dilim ekmek konur. Dönüş yolunda ekmek, kedi veya köpeğe verilir; kömür ve yumurta ise eve getirilir. Anne, yumurtayı sütünün çoğalması için yer. Bu sayede anne ve bebek nazara karşı da korunmuş olur" (Karabüber, 2017: 56, 74).
\end{abstract}

Diyarbakır, İzmir, Tekirdağ ve Midyat’ta kırkı çıkıp ilk gezmesine giden kadına şeker ve yumurta hediye olarak verilir (K7, K18, K19; Artun, 1998: 6; Uygur, 2008: 27, 43). Bitlis'te yeni doğan bir bebek, herhangi bir aile büyüğünün evine ilk defa ziyarete götürüldüğünde ev sahibi aile tarafından bebeğin annesine yumurta verilir. Böylece bebeğin çabuk büyüyeceğine ve sağlıklı olacağına inanılır (K25). Denizli'de kırkı çıkarılan ve babanın ailesinin yanına ilk kez gezmeye götürülen bebeğe yumurta hediye edilir. Yumurta hediye edilmeyen çocuğun ileriki yaşamında hırsız olabileceği ya da fareler tarafından rahatsız edilebileceği belirtilir (Çelebi, 2017: 262). Diyarbakır'da lohusa ve bebeğin doğumdan sonraki kırk günlerini tamamlamalarının ardından çıktıkları ilk gezmeye "kırk uçurma" veya "kırk çıktı" denir. Anne, ilk gezmesini kendi annesinin evine giderek gerçekleştirir. Ziyarette genç anneye hem kendisinin hem de bebeğinin sarılık olmaması için yumurta yedirilir (Karakaş, 2020: 34). Muğla'nın Yatağan ilçesinde kırkını çıkarmış bebek, ev gezmesine çıktığı gün ev sahibi aile tarafından üç yumurtayı temsilen çocuğun kundağına süslü üç şey iliştirilir. Bütün bunlarla çocuğun hayatının yumurta gibi parlak ve sağlam olması temenni edilir (Eşmeli, 2006: 53). Muğla’nın Köyceğiz ilçesinde ilk gezmesine çıkacak olan bebeğin kundağına aile büyüklerinden biri tarafından bir adet yumurta bırakılır. Bebeğe "sağlık" dilemek temennisiyle bırakılan yumurta, anne tarafından hemen geri alınır (K12). Malatya'nın Arapgir ilçesinde bebek, sokağa ilk kez çıktığında kundağının arasına ekmek, yumurta ve şeker konulur. Bu hediyeler, bebek ve lohusanın karşısına çıkan ilk kimseye verilir (Köksal, 2018: 7). Kastamonu'nun Abana ilçesinde de ilk gezmesine çıkan bebeğe yumurta verilir (Yıldız, 2002: 558). Rize'de kırkı çıktıktan sonra anneye mendil, para veya yumurta hediye edilir (Kabataş, 2006: 33). İzmir'in Tire ilçesinde gidilen evde bebeğe sağlıklı olsun diye yumurta; ağzı sözü tatlı olsun diye şeker, kurabiye, çikolata, eli bereketli olsun diye biraz un verilir (Aydınoğlu, 2005: 62). Balıkesir'de kırk uçurmak için teyze, hala, yenge gibi yakın akrabalara ziyarete gidilir. Ziyaret dönüşü ev sahibi aile tarafından bebeğin daha güzel olması için kundağının ya da kıyafetlerinin arasına üç beş tane yumurta konur (K21). Balıkesir'de kırk uçurmak için komşulardan birine de gidilebilir. Uygulama, bebeğin sağlıklı bir şekilde 
büyümesi için yapılır. "Kırk uçurma" eyleminde esas unsur olan yumurta; kız çocuğunun göğüslerinin, erkek çocuğunun ise testislerinin büyük olması amacıyla bebeğin giysilerinin arasına konur (K22). Denizli yöresinde de k1z çocuklarına hediye edilen yumurta ile kızların göğüslerinin yumurta gibi olması arasında ilişki kurulur (Çelebi, 2017: 262).

Diyarbakır'da yumurta kabuğu, kırklama ritüelinde su doldurma kabı olarak kullanılır. "Kırklama" pratiğinin sonunda bir yumurtanın kabuğu yardımıyla "kırk tası"nın içine kırk kez su boşaltılır; bu su, bebeğe dökülerek kırklama tamamlanır (K7). Muğla’nın Köyceğiz ilçesinde bebeğin doğumunun kırkıncı gününde bir leğen içinde tuzlu su hazırlanır ve içerisine bir tane yumurta konur. Bebek, bu suda güzelce yıkanır (K12). Bitlis’te bebeğin kırk1 çıkarılırken beşiğin altına bir yumurta kırılır. Bir gün sonra yumurtaya bakılır. Yumurtanın sarısının dağılmaması, bebeğin ömrünün uzun olacağına yorumlanır (K25).

Görüldüğü üzere halk kültüründeki doğum sonrası geleneklerden olan bu uygulamalarda yöreden yöreye bazı farklılıklar bulunmaktadır. Ancak tüm uygulamalarda ortak payda olan yumurta, lohusanın üreme yetisinin temsil edilmesinin belki de devamlılığının bir ifadesi olarak işlev görmektedir.

Türk halk kültüründe doğumdan sonraki kırk günlük süreci, sağlıklı bir şekilde tamamlayamayan, sıklıkla hastalanan ve devamlı ağlayan bebeklere "kırk basığı" teşhisi konur; ardından tedaviye geçilir. Kırk bası̆̆ı olan bebeği tedavi etmek için çeşitli yollar vardır. Bunların bir bölümünde yumurta kullanılır:

“Zile'de bu tür çocuklar için yumurta dondurtma işlemine başvurulur. Bu işlem için bir ocak vardır. Kırk basığı olan çocuğun ailesi, ocağa bir yumurta götürür. Ocak sahibi, yumurtayı bir sahanın içine kırar. Belli bir süre bekleyen yumurta donar. Çocuğun ailesi bahşiş vererek yumurtayı alır. Yumurta eve getirilirken yedi kapıdan yedi tane odun parçası toplanır. Toplanan odunlarla yakılan ateşin üstünde su kaynatılır. Dondurulan yumurta kaynatılan suyun içine konur ve bu suyla çocuk yıkanır. Böylece kırk basığı olan çocuğun iyileşeceğine inanılır. Aynı uygulama çocuğun kırkı çıkarılırken de yapılır” (Sezmiş, 2018: 49).

“Rize'de (Kabataş, 2006: 35) yeni ayın ilk çarşambasında içine yumurta kırılan bir tas, çocuğun başında dolandırılır. Antalya'nın Korkuteli ilçesinde "kırk suyu”na yumurta kabuğu ile kırk defa su ilave edilir (Gönenç, 2011: 14). Görüldüğü üzere yumurta, "kırk çıkarma” ve "kırk uçurma" ritüellerinde olduğu gibi "kırk basması" adı verilen rahatsızlığın tedavisinde de kullanılan önemli simgesel bir varlıktır.

\section{Bebeğin ilkleriyle ilgili uygulamalarda yumurta}

Her ne kadar doğum, evlenme ve ölüm adı verilen üç ana geçiş döneminden bahsediliyor olsa da esasında bir bireyin gelişim sürecinde birçok geçiş dönemiyle yüz yüze kaldığı yadsınamaz. Bir bebeğin ilk kez yürümesi, konuşması, ilk dişini çıkarması, anne sütünden kesilmesi gibi süreçler bu bağlamda dikkati çeker. Türk halk kültüründe bebeğin gelişim sürecini yansıtan bu değişikliklere yönelik yapılan uygulamalarda yumurtadan yararlanıldığı görülür. Örneğin Siirt' in Baykan ilçesinde rafadan pişirilen iki yumurta, gece damda bekletilir. 
Sabahleyin bu yumurtalar çocuğa yedirilir. Böylece çocuğun hemen memeden kesileceğine inanılır (Tardu, 1996: 37). Tire' de çocuğu memeden keserken su dolu bir kabın içine yumurta konularak "Memeden nasibin kesildi başka yerden açık olsun.” denir (Aydınoğlu, 2005: 66) "Çocuk emeklemekten kurtulup ilk adımını atarken bir testi ağzına yumurta konur ve çocuğa gösterilir. Çocuk bu yumurtayı alırken "Memeden nasibin kesildi, yiyecekten açılsın.” denir. Çocuk, adım atınca ayağı büyüklüğünde poğaça yapılarak fakirlere dağıtılır (Aydınoğlu, 2005: 67). Kayseri'de yaşayan Uygur ve Kazak Türklerinde sünnet edilen çocuğa getirilen hediyeler arasında mutlaka yumurta bulunur (Köylü, 2017: 102).

Türk halk kültüründe ilk dişini çıkaran çocuk için yapılan ve yöreden yöreye "hedik, gölle, diş aşı, diş bulguru, dirgit, gilgidir” gibi değişik adlarla anılan törensel uygulamada yumurtanın bebeğe verilen hediyeler arasında olması dikkat çekicidir. Geleneksel uygulamaya göre komşulara ikram edilen hedik/gölle dolu tabaklar boş gönderilmez. Tabaklar, Afyon'un Bolvadin ilçesinde (Güldemir, 2008: 57) içine yumurta, para veya elbise; Sivas'ın Divriği ilçesinde ise (Gökdemir, 2011: 74) iki yumurta ve mendil konularak geri verilir.

Türk halk kültüründe geçiş dönemlerinin ilk basamağı olan doğum sürecinin hemen her aşamasında yumurtanın simgesel anlamlarından istifade edilir. Hamile kalmak isteyen kadınlar tarafından kutsal mekânlara yumurta bırakılması, kırk çıkarmada kullanılacak suyun bir bölümünün yumurta kabukları ile taşınması, kırkı çıkan bebeğe ilk gezmesinde yumurta hediye edilmesi gibi dinsel ve büyüsel terkiplerle doğurganlık ve üretkenlik beklentisi dışa vurulur.

\section{Evlenme ve yumurta}

Kadın ve erkeğin -çoğu zaman- hem resmî hem de dinî olarak birlikteliğinin ifadesi olan evlenme, dünya üzerindeki hemen her yerde çeşitli inanışlara ve ritüellere sahne olmaktadır. Türk halk kültürü bu geçiş süreciyle ilgili olarak -bazı bölgelerde azalmış olsa da- zenginliğini korumaktadır. Halk kültüründe önemli bir geçiş dönemi olarak kabul edilen "evlenme" töreni kapsamında birçok inanış ve ritüel bulunur. Geçiş sürecindeki gelin ve damadı koruma esasına dayanan uygulamalarda doğadaki bazı simgesel varlıklardan istifade edilir. Bunlardan biri olan yumurta, evlilik töreninin belirli aşamalarında, bölgeden bölgeye değişkenlik göstermekle beraber, evlenecek çiftlere doğurganlık, üretkenlik anlamlarını temsil edecek şekilde seremonilerde yerini alır.

Özbekistan'da nikâh toyunda bekârlara birer adet pişmiş yumurta ikram edilir (Kalafat, 2012: 218). Hive bölgesindeki Özbeklerde gelin, nakışlarla süslenmiş bir çay torbası hazırlayıp içine yumurta koyarak damada gönderir. Damat ve arkadaşları bu yumurtaları yer (Snesarev, 1963; Aktaran: Mayidarova 2017: 39). Türkmenlerde bazı boylarda dügün günü boyalı yumurtalar yüksek yerden aşağı yuvarlatılır. Bu gelenek, Tacikistan'ın dağlık bölgelerinde sürdürülmektedir (Vasilyeva, 1954; Aktaran: Mayidarova, 2017: 39).

Siirt ve Diyarbakır'da bir yumurta kırılarak tabağa alınır. Gelin; yeni evine girerken yumurtaya buladığı elini, kapı başındaki duvara sürer (Karakaş, 2020: 52). Siirt'in Baykan ilçesinde gelinin yüzünün yumurtanın beyazı gibi ak olması temennisiyle önüne yumurta atılır (Tardu, 1996: 49). Konya'nın Selçuklu, Şanlıurfa'nın Suruç ilçelerinde, Elazı̆̆ Muş 
ve Diyarbakır'da yeni gelin eve girerken duvarda ve kapı başında yumurta kırılır (Arıcı, 2018: 116; Atmaca, 2006: 41; K5, K11, K23). Şırnak'1n Cizre ilçesinde hem gelin hem damat tarafından evin giriş kapısına çiğ yumurta atılır (Yaşın, 2007: 327). Konya’nın Cihanbeyli ilçesinde yeni gelinin evine, herhangi bir yere, kayınvalidesi tarafindan bir sepet yumurta konur. Uygulamada gelinin çocuklarının çok ve yumurta gibi güzel olması amaçlanır. Aynı zamanda bu yumurtalarla yeni kurulacak aile için "bereket" temenni edilir (K20). Sinop, Giresun ve Gaziantep’te dügüun günü kız evine yumurta asılır (Başoğlu, 1980 ve Köksal, 1996'dan Aktaran: Yeşil, 2012: 191).

Adana'da geline veya gelin ve damada kısırlık olmasın diye yumurta yedirilir (Akyol, 2006: 99; Başçetinçelik, 2009: 276). Nevşehir'in Derinkuyu ilçesinde “yeni geline yumurta yedirilirse çocuğu olacağına inanılır” (Kabak, 2011: 27). Türkmenistan’ da düğün günü gelin ve damada yumurta yedirilir (K10).

Türk halk kültüründe yenilen yiyeceklerin insan yaşamı üzerinde olumlu veya olumsuz etkisi olduğuna inanılır. Bilhassa geçiş dönemlerinde, özel günlerde veya kutsal mekân ziyaretlerinde belirli yiyeceklerin yenmesine özen gösterilir. Bu bağlamda yumurtanın da evlenme sürecinde doğurganlığı sağlama ve bereketi arttırma amaciyla gelin ve damada yedirilmesi dikkate değerdir.

Bitlis'in Ahlat ilçesinde düğünden bir/iki gün önce yapılan "hamur gecesi”"nde bollukbereket temennisiyle damadın başı üzerine un elenip yumurta kırılır. "Un ve yumurtalar, çoğunlukla komşular tarafından getirilir. Bu malzemelerle aynı zamanda düğün çöreği de yapılır” (K15). Geleneğin benzeri, Hatay’ın Hassa ilçesinde kına gecesinde erkek kınası yapılırken uygulanır. Damadın arkadaşları tarafından damadın kafasına yumurta kırılır ve un dökülür (K27). Afyonkarahisar'da ise kına gecesinde hem damadın hem de sağdıcın kafasında çok sayıda yumurta kırılır. Bursa'nın İnegöl ilçesinde “güvey batması” olarak adlandırılan ritüel, damat ve sağdıcın una bulanmaları, başlarında yumurta kırılması ve sonra derede yıkanmaları şeklinde gerçekleştirilir. Bilecik'te ise daha önce yola bırakılmış yumurtalar damat tarafindan kırılır. "Dügü̈n günü Kütahya'da yaşayan Balkan göçmenlerinin avcı erkekleri tarafindan bir ağaca iple asılmış yumurta, vurulmaya çalışılır” (İmren, 2009: 41).

Yumurta üremenin simgesidir. Yumurta ile ilgili tüm uygulamalarda gelinin üretkenlik gücünü etkilemek ve pekiştirmek amaçlanmaktadır. Bir anlamda doğrudan söze dökülemeyen istekler, sembol nesneler aracılığıyla ifade edilmektedir. Türk halk kültüründe geçiş dönemlerinin ikincisi olan evlenme töreninde yumurtanın işlevsel olarak kullanıldığı görülür. Kapı başına yumurta atılması, kız evine yumurta asılması, gelin ve damada yumurta yedirilmesi vb. uygulamalarda "üretkenlik" temenni edilmekte; yumurtanın işlevsel ve sembolik gücünden istifa edilmek istenmektedir.

\section{Ölüm ve yumurta}

Türk halk kültüründe geçiş dönemlerinin sonuncusu olan ölüm olayıyla ilgili birçok inanış ve uygulama bulunmaktadır. Bunlar arasında yumurtayla ilişkili olanlar da vardır: Çuvaşlarda (Arık, 2012: 110) kişinin ölümünün 3. ve 7. günlerinde evde börek, poğaça, 
yumurta gibi yiyecekler hazırlanır; ölünün adı belirtilerek ve ‘önünde olsun’ denilerek bunlardan birer parça kesilir ve boş bir tabağa konur. Yakılan bir mum eşliğinde hazırlanan kaplar evin dışına bırakılır. "Mardin'in Midyat ilçesinde yaşayan Hristiyanlar, taziyeleri varsa, ilk paskalya bayramında yumurtayı beyaz bırakırlar. Böylece herkes o evde taziye olduğunu bilir" (Uygur, 2008: 87). Zile'de genç yaşta ölen evli ya da nişanlı kadının mezarına iki tane yumurta konulur. Bu işlem, ölen kadının kocası yeniden evlenirse kadının ruhunun kocasını kıskanmasını engellemek ve rahat etmesini sağlamak için yapılır. Bu işlem yapılmadığı takdirde ölen kadının gözünün kalacağına ve patlayacağına inanılır (Sezmiş, 2018: 70). Merzifon'da (Serdaroğlu, 2018: 116) şeytanın yumurta kabukları içine girmemesi ve ölüm hâlindeki kişiyi aldatıp su içirmemesi için gündelik yaşamda beslenmek için kullanılan yumurtaların kabukları iyice ezilir. Tosya'da (Karabüber, 2017: 109) tuvalete tükürülen tükürüğün şeytan tarafından alınabileceği ve bu tükürüğün yine şeytan tarafından yumurta kabukları içine konularak ölmek üzere olan kişiye "su" olarak içirilebileceği endişesiyle yumurta kabukları ufak parçalara ayrılır.

Mitolojiden günümüze yumurtayla ilişkili birçok halk inanışı ve uygulaması mevcuttur. Tüm bunlarda yumurta, bir tür kutsallık ve sıra dışı değeriyle "simge varlık" olma vasfını korumuştur. Halk arasında akıl ve sağduyu ile izahı yapılan/yapılamayan bu inanış ve ritüeller, toplum tarafından özümsenmiştir.

\section{Sonuç}

Yumurtanın simgesel anlamı, tarih öncesi devirlerden bu yana çeşitli ayinlerde ve mitlerde kendisini korumuştur. Yumurtanın köşesiz, çıkıntısız ve oval yapısı, canlı taşıma özelliğine sahip olması gibi sebepler, onu muhtelif törenlerin başaktörü yapmıştır. Yumurtaya yönelik her tür uygulama ve inanış, farklı ihtiyaçlar temelinde tekrarlandıkça yeniden üretilmiştir. Çoğu birden fazla işleve sahip ve çok anlamlı olan bu üretimler, zamanla değişerek ve dönüşerek geçmiş yıllardan bu yana gerçekleştirilen dizgelere eklemlenmiştir.

Eliade, yumurtanın "doğum değil, dönüş ve yenilenme olarak yeniden yaradılışı simgelediğini" belirtir. Ancak bazı durumlarda yenilenme, "doğurganlık” yetisinin olmasıyla ilintilidir. Geleneksel kültürde evlenme töreninde kullanılan yumurta, doğrudan doğurma yetisine atıfta bulunmaktadır. Ayrıca çocuk sahibi olmak isteyen kadının kullandığı büyüsel yöntemlerde yumurtanın "doğurganlık" ile olan bağı, bu hususta dikkat çekicidir.

Türk halk kültüründe geçiş dönemleri kapsamındaki yumurta uygulamaları, onun biçimsel ve işlevsel özelliklerinden ilham alır. Bu pratiklerde kullanılan yumurta ile ritüelin başkahramanlarına müdahale edilmek istenir; bu sayede birey/bireyler üzerinden köklü değişiklikler yapmak amaçlanır. Bu hususta en çok istenen ise doğurganlığın, üretkenliğin, canlanmanın ve yenilenmenin yolunu aralamaktır. Yukarıda tespit edilen tüm bu dinsel ve büyüsel işlemlerde sıradan bir besin kaynağı olmanın ötesinde telakki edilen yumurtanın simgesel dilinden ve farklı anlamsal katmanlarından yararlanılır. 


\section{Kaynakça}

Abdurrezzak, A.O. (2019). Kalevala destanından hareketle yaratılış mitinden günümüz halk inanışına uzanan kozmik yumurta motifi. Türük, Uluslararası Dil, Edebiyat ve Halkbilimi Araştırmaları Dergisi, 16, 234-248.

Akyol, N. S. (2006). Adana (Merkez) halk kültüründe halk inançları bayram ve törenler. Basılmamış yüksek lisans tezi, Adana: Çukurova Üniversitesi.

Arıcı, B. (2018). Konya ili Selçuklu ilçesi halk inanışları. Yüksek lisans tezi, Uşak: Uşak Üniversitesi

Arık, D. (2012). Hıristiyanlaştırılan Türkler Çuvaşlar. Ankara: Berikan.

Aslan, M. G. (2011). Kayseri ili Pınarbaşı ilçesindeki Avşar köylerinde Türk halk inanışları. Yüksek lisans tezi, Niğde: Niğde Üniversitesi.

Ateş, F. (2019). Mitolojiden günümüze yumurta ve "kırk uçurma" geleneği. Avrasya Uluslararası Araştırmalar Dergisi, 7(19), 14- 27.

Atmaca, İ.(2006). Suruçveçevresi halk inanışlarının dinler tarihi açısından değerlendirilmesi. Yüksek lisans tezi, Elazı̆̆: Fırat Üniversitesi.

Aydınoğlu, B. (2005). Tire merkezinde halk inanışları. Yüksek lisans tezi, Manisa: Celal Bayar Üniversitesi.

Balcı, F. (2019). Kuzey Kıbrıs Türk halk kültüründe geçiş dönemleri ve bunlara bağlı inanışlar. İstanbul: Hiperlink.

Başçetinçelik, A. (2009). Adana halk kültüründe doğum-evlenme-ölüm. Adana: Altınkoza.

Boratav, P. N. (1994). 100 Soruda Türk folkloru. İstanbul: Gerçek.

Campbell, J. (2010). Kahramanın sonsuz yolculuğu. İstanbul: Kabalc1.

Çelebi, M. S. (2017). Türk kültür evreninde toy Denizli örneği. Ankara: Kömen.

Çıblak C. N. (2011). Mersin'de doğumla ilgili âdetlerin halk hekimliği yönünden incelenmesi. Lokman Hekim Journal, 1(3), 1-12.

Çinpolat, S. (2009). Karaçay halk inanışları ve uygulamalarının dinler tarihi açısından değerlendirilmesi (Tokat örneği). Yüksek lisans tezi, Kayseri: Erciyes Üniversitesi.

Demir, H. (2006). Ergani folkloru. Lisans Tezi, Diyarbakır: Dicle Üniversitesi.

Eliade, M. (2009). Dinler tarihine giriş. İstanbul: Kabalc1.

Erhat, A. (2013). Mitoloji sözlüğü, İstanbul: Remzi.

Eşmeli, İ. (2006). Muğla-Yatağan ve çevresi halk inanışları ve uygulamaları üzerine bir araştırma. Yüksek lisans tezi, İzmir: Dokuz Eylül Üniversitesi.

Frazer, J. G. (2017). Altın dal, dinin ve folklorun kökleri. (M. H. Doğan, Çev.) İstanbul: Yapı Kredi.

Gider, Ş. (2009). Halk dindarlı̆̆ının bir göstergesi olarak adak ve ziyaret fenomeni İstanbul örneği. Yüksek lisans tezi, Kayseri: Erciyes Üniversitesi.

Goyal, D. (2016). Perinatal practices \& traditions among Asian Indian women. The American Journal of Maternal/Child Nursing: 41(2), 90-97. 
Gökdemir, İ. (2011). Divriği ilçesinde yaşayan Alevilerde dinî hayat ve yaygın halk inanışları. Yüksek lisans tezi, Sivas: Cumhuriyet Üniversitesi.

Gönenç, A. (2011). Antalya ili Korkuteli ilçesinde halk inanışları ve halk hekimliği. Yüksek lisans tezi, Konya: Selçuk Üniversitesi.

Green,N.(2006). Ostricheggs and peacock feathers: sacred objects as cultural exchangebetween Christianity and Islam. Al-Masāq, 18(1), 27-78, DOI: 10.1080/09503110500222328.

Gülbay Küçük, S. (2012). Elazı̆̆ Fevziçakmak, Esentepe ve Yıldızbă̆ları Mahallelerinde oturan Tunceli göçmeni Alevilerde halk inanışları ve bunlara bağlı uygulamalardaki değişimler. Yüksek lisans tezi, Elazığ: Fırat Üniversitesi.

Güney A. S. (2015). Erzurum'da kadınla ilgili halk inanışları. Yüksek lisans tezi, Erzurum: Atatürk Üniversitesi.

Güngör, H.; Köylü B. (2017). Türk halk inanışları üzerine notlar. Kayseri: Kimlik.

Hançerlioğlu, O. (2010). Dünya inançları sözlüğü. İstanbul: Remzi.

Helimoğlu, Y. (2017). Diyarbakır efsaneleri derleme-inceleme. İstanbul: Cumhuriyet Kitapları.

Ivanits, L. J. (1989). Russian folk belief. London and New York: Routledge Taylor\&Francis Group.

İmren, M. K. (2009). Kütahya'da yaşayan Balkan göçmenlerinin halk inanışlarının dinler tarihi açısından değerlendirilmesi. Yüksek lisans tezi, Elazı̆̆g: Fırat Üniversitesi.

Kabak, T. (2011). Derinkuyu yöresi halk İnanışları. Yüksek lisans tezi, Nevşehir: Nevşehir Üniversitesi.

Kabataş, F. (2006). Rize ve çevresindeki yaygın halk inanışları. Yüksek lisans tezi, Elazı̆̆: Firat Üniversitesi.

Kahraman, Ö. (2010). Elâzı̆̆ ve çevresinde yaşayan Zazalardaki halk inanışlarının dinler tarihi açısından değerlendirilmesi. Yüksek lisans tezi, Elâzı ̆̆: Fırat Üniversitesi.

Kalafat, Y. (2012). Türk halk inançlarında beslenme, Ankara: Berikan.

Karabüber, T. (2017). Tosya halk inanışları. Yüksek lisans tezi, Çankırı: Karatekin Üniversitesi.

Karakaş, R. (2013). Diyarbakır'da bebeğin ilkleri hedik köstek kesme törenleri ve çocuklara yönelik halk hekimliği uygulamaları. Karadeniz (Black Sea), 4(16), 74-88.

Karakaş, R. (2020). Güneydoğu Anadolu halk inanışları (Dicle Bölümü). Ankara: Gazi.

Karanfil Güldemir, M. (2008). Afyon-Bolvadin ve çevresi halk inanışları ve uygulamaları. Yüksek lisans tezi, İzmir: Dokuz Eylül Üniversitesi.

Kılıç, S. (2012). Sivas ili Ulaş ilçesi halk inanışları. Yüksek lisans tezi, Elazığ: Fırat Üniversitesi.

Kıyak, A. (2005). Baskil ve çevresinde yaygın halk inanışları. Yüksek lisans Tezi, Elazı̆̆: Frrat Üniversitesi. 
Kim, H. J. (2004). Baraba Türklerinin Jestey Möngkö masalındaki mitolojik motifler üzerine. Bilig Türk Dünyası Sosyal Bilimler Dergisi, 28, 43-57.

Köksal, H. (2018). Malatya ili Arapkir ilçesi halk inanışları. Yüksek lisans tezi, Elazığ: Fırat Üniversitesi.

Leach, M. (1950). Standart dictionary of folklore myhtology and legends. London: Funk and Wagnalls co.

Madiyarova, S. (2017). Karakalpak Türkleri eski halk inançları. Yüksek lisans tezi, Ankara: Yıldırım Beyazıt Üniversitesi.

Magat, M. (2002). Balut fertilized duck eggs and their role in Filipino culture. Western Folklore, 61(1), 63-96.

Muhammad, R. vd. (2013). The roles and symbolism of foods in Malay wedding ceremony. Procedia-Social and Behavioral Sciences 101, 268-276.

Najafov, A. (2019). Azerbaycan halk inanışları. Yüksek lisans tezi, Konya: Necmettin Erbakan Üniversitesi.

Newall, V. (1967). Easter eggs. The Journal of American Folklore, 80 (315), 3-32.

Newall, V. (1971). An egg at easter: A folklore study. London: Routledge and K. Paul.

Örnek, S. V. (1979). Geleneksel kültürümüzde çocuk. Ankara: İş Bankası.

Parlayan, M. (2012). Tunceli ve çevresinde halk inanışları. Yüksek lisans tezi, Elazığ: Fırat Üniversitesi.

Serdaroğlu, Ö. F. (2018). Merzifon ve çevresinde halk inanışlarl üzerine bir araştırma. Yüksek lisans tezi, Ankara: Ankara Üniversitesi.

Sezmiş, M. E. (2018). Kültürel değişim bağlamında Zile ilçesinde Türk halk inanışları. Yüksek lisans tezi, Samsun: On Dokuz Mayıs Üniversitesi.

Şimşek, A. (2013). Manavgat yöresi halk inanışları. Yüksek lisans tezi, Isparta: Süleyman Demirel Üniversitesi.

Tapp, N. (1989). Hmong religion. Asian Folklore Studies, 48(1), 59-94.

Tanyıldızı, E. (2015). Elâzığ halk kültüründe doğum âdetleri. Turkish Studies International Periodical For The Languages, Literature and History of Turkish or Turkic 10(12), 1067-1084.

Tardu, T. (1996). Siirt ili Baykan ilçesi folkloru. Mezuniyet tezi, Diyarbakır: Dicle Üniversitesi.

Uçak, S. (2007). Ergani'de eski Türk inançlarının izleri ve halk hekimliği. Yüksek lisans tezi, Kütahya: Dumlupınar Üniversitesi.

Uygur, H. K. (2008). Midyat halk kültürü monografisi. Yüksek lisans tezi, Diyarbakır: Dicle Üniversitesi.

Yaşın, A. (2007). Tarih kültür ve Cizre. Ankara: Kuloğlu.

Yeşil, Y. (2012). Türk dünyasında geçiş dönemi ritüelleri ve bu ritüellerde icra edilen türler. Doktora tezi, Ankara: Gazi Üniversitesi. 
Yıldırım, H. (2013). Erzincan Kemaliye ilçesindeki yaygın halk inanışları. Yüksek lisans tezi, Elazı ğ: Fırat Üniversitesi.

Yıldız, N. (2002), Kastamonu'nun ilçesi Abana'da halk kültürü. Erdem, Türk Halk Kültürü Özel Sayıs1-III, C. 13, S. 39, s. 551-569.

\section{Kaynak kişiler}

K1: Sabahat Ekin, 1962 doğumlu, ilkokul mezunu, kuaför, Siirt, 11.03.2020

K2: Şamiran Özsabuncu, 1966 doğumlu, okuryazar, ev hanımı, Siirt, 11.03.2020

K3: Rabia Özsabuncu, 1960 doğumlu, lise mezunu, kuaför, Siirt, 11.03.2020

K4: Ayhan Gün,1990 doğumlu, üniversite öğrencisi, Batman, 11.03.2019

K5: Kudret Yıldırım, 1933 doğumlu, okuryazar değil, ev hanımı, Diyarbakır, 10.01.2021

K6: Naciye Bandeoğlu, 1955 doğumlu, okuryazar değil, ev hanımı, Çermik/Diyarbakır, 18.11.2020

K7: Nafiye İlter Altan, 1974 doğumlu, üniversite mezunu, sınıf öğretmeni, Diyarbakır/ Ergani, 14.11.2020

K8: Meryem Nigiz, 1941 doğumlu, okuryazar değil, ev hanımı, Şırnak/Cizre, 08.04.2017

K9: Evin Nigiz, 1997 doğumlu, üniversite öğrencisi, Şırnak/Cizre, 08.04.2017

K10: Mahrijemal Esenova, 1985 doğumlu, üniversite öğrencisi, Türkmenistan/Aşkabat, 18.10.2019

K11: Nuri Ek, 1979 doğumlu, ilkokul mezunu, esnaf, Diyarbakır/Kocaköy, 10.01.2019

K12: Gizem Dak, 1989 doğumlu, doktora öğrencisi, eğitim yöneticisi, Muğla/ Köyceğiz, 27.12.2020

K13: İnci Aytı, 1977 doğumlu, okuryazar, serbest meslek, Bursa/ Orhangazi, 26.12.2020

K14: Hikmet Özenç, 1950 doğumlu, ilkokul mezunu, Siirt/Kurtalan, 12.10.2018

K15: Songül Ülgen, 1995 doğumlu, üniversite mezunu, Bitlis/Ahlat, 03.12.2020

K16: Tuba Aykal, 1993 doğumlu, üniversite mezunu, Diyarbakır/Bismil, 04.11.2020

K17: Ayten Orhan, 1980 doğumlu, lise mezunu, Diyarbakır (Ankara'da ikamet ediyor), 21.12.2020

K18: Abdülkadir Öçalır, 1950 doğumlu, lise mezunu, emekli, Diyarbakır/Merkez (İzmir'de ikamet ediyor), 21.12.2020

K19: Sabiha Öçalır, 1961 doğumlu, ilkokul mezunu, ev hanımı, Diyarbakır/Merkez (İzmir'de ikamet ediyor), 21.12.2020

K20: Fatma Otal, 1977 doğumlu, okuryazar, serbest meslek, Konya/Cihanbeyli, 25.12.2020

K21: Seher Paçalı, 1969 doğumlu, okuryazar, pazarc1, Balıkesir/Manyas, 27.12.2020.

K22: Sevim Aktaş, 1965 doğumlu, okuryazar, ev hanımı, Balıkesir/Manyas, 27.12.2020.

K23: Mücahit Kumandaveren, 1973 doğumlu, üniversite mezunu, memur, Muş, 06.01.2021

K24: Nacide Başlak, 1970 doğumlu, ilkokul mezunu, ev hanımı, Van, 06.01.2021 
K25: Sebahat Ok, 1975 doğumlu, ilkokul mezunu, ev hanımı, Bitlis, 06.01.2021

K26: Hikmet Özenç, 1950 doğumlu, ilkokul mezunu, Siirt/Kurtalan, 20.08.2020

K27: Özcan Vuran, 1995 doğumlu, üniversite öğrencisi, Hatay/Hassa, 23.02.2021

(Not:Bu çalışmaya yönelik Siirt Üniversitesi Etik Kurulu 18.02.2018 tarih 15 sayılı oturumunda oybirliğiyle onay vermiştir.)

\section{Elektronik kaynaklar}

Ur11: Ethnography of communication: A Discourse Analysis with Dell Hymes "Sepaking Model" in Kahiyang-Bobys's Traditional Javanese Wedding Ceremony. (arkinharis.com). Erişim Tarihi: 10.04.2020

Url2: https://www.artsrn.ualberta.ca/folkloreukraine/?page_id=9,Erişim Tarihi: 10.04.2020

Url 3: http://www.unm.edu/ cheo/LONG.pdf, Erişim Tarihi: 11.05.2020

Url4: http://turkoloji.cu.edu.tr/HALKBILIM/artun_tekirdag_evlenme.pdf, Erişim Tarihi: 17.04.2020

Ur15: http://www.caglarerbek.com/2015/05/turklerde-yasam-agaci.html, Erişim Tarihi: 10.01.2021

Ur16: https:/www.trtavaz.com.tr/haber/tur/avrasyadan/kazakistanin-gurur-kaynagi-bayterek-kulesi/5b 2b889d01a30a23942b1977, Erişim Tarihi: 10.01.2021

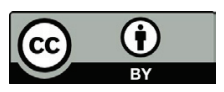

Bu eser Creative Commons Atıf 4.0 Uluslararası Lisansı ile lisanslanmıştır.

(This work is licensed under a Creative Commons Attribution 4.0 International License). 